19 | 1997

Varia

\title{
Sir Balthazar Gerbier et la machine à calculer de Pascal
}

Hartlib Papers Project

Mark Greengrass

\section{(2) OpenEdition \\ Journals}

Édition électronique

URL : http://journals.openedition.org/ccibp/558

DOI : $10.4000 /$ ccibp. 558

ISSN : 2493-7460

Éditeur

Centre international Blaise Pascal

Édition imprimée

Date de publication : 5 avril 1997

Pagination : 10-16

ISSN : 0249-6674

Référence électronique

Mark Greengrass, « Sir Balthazar Gerbier et la machine à calculer de Pascal », Courrier du Centre international Blaise Pascal [En ligne], 19 | 1997, mis en ligne le 06 janvier 2016, consulté le 15 septembre 2020. URL : http://journals.openedition.org/ccibp/558

Ce document a été généré automatiquement le 15 septembre 2020

Centre international Blaise Pascal 


\title{
Sir Balthazar Gerbier et la machine à calculer de Pascal
}

\author{
Hartlib Papers Project
}

Mark Greengrass

1 Parmi les manuscrits de l'encyclopédiste et "agenceur " du dix-septième siècle Samuel Hartlib, maintenant conservés à la bibliothèque universitaire de Sheffield, se remarque un ensemble de lettres de 1648-1649 provenant de Sir Balthazar Gerbier et le concernant en 1648-491. Gerbier était à Paris jusqu'au début de l'été 1649 où il revint en Angleterre. Dans une de ses lettres, datée du 4 octobre 1648, il fournit une description intéressante de la machine à calculer de Blaise Pascal accompagné de ses commentaires initiaux ${ }^{2}$.

2 Sir Balthazar Gerbier (1591-1667) était un individu entreprenant dont les nombreuses mésaventures affectèrent peu l'enthousiasme ${ }^{3}$. Il est né à Middelburg dans une famille de réfugiés français. Ayant passé quelque temps en Gascogne à la cour du roi Henri IV, il est engagé au service du Prince Maurice de Nassau dans les Pays-Bas en tant que dessinateur prometteur dans le génie militaire. De là, il va à Londres en 1616 pour se joindre à l'entourage de l'ambassadeur de Hollande, avant d'être employé par le duc de Buckingham, George Villiers. Les années qui suivent furent les plus prospères et réussies de sa carrière. Alors que Buckingham jouit de la faveur royale, Gerbier se construit une réputation d'inventeur et de directeur de projets. Il dessine des machines de guerre qui pourraient être utilisées pour briser le siège de La Rochelle, sert de secrétaire des codes à Buckingham, et est employé dans quelques missions d'espionnage à Bruxelles et à Paris. Il fait une demande de naturalisation au Parlement en 1628, mais sa requête est presque refusée à cause de ses liens avec l'impopulaire Buckingham. Par la suite, il passe la plupart des dix années qui suivent en mission pour Charles Ir à Bruxelles, où les coûts que lui occasionne son service dépassent de loin ses moyens. Les dettes contractées au cours de son service dans les années 1630 le poursuivent jusqu'à la fin de sa vie. Quand il est compromis dans des affaires conclues au nom de Charles $\mathrm{I}^{\mathrm{er}}$ avec des membres mécontents de la noblesse du sud des Pays-Bas, il est péremptoirement rappelé au début de l'été 1641. Mais sa situation financière est 
alors telle qu'il peut à peine emprunter de quoi rapatrier sa femme et ses enfants en Angleterre. Malgré ses réclamations à la trésorerie et à Charles $\mathrm{I}^{\mathrm{er}}$ pour être dédommagé de ses pertes, la guerre civile ne lui laisse pas le choix et il fuit ses créanciers en 1643. Il se rend en France avec une lettre de Charles I le recommandant à Louis XIII, qui meurt peu avant son arrivée à Dieppe.

Une fois à Paris, Gerbier tente d'exploiter le peu d'influence qu'il peut glaner à la cour du roi de France. Il reçoit une lettre patente du 3 septembre 1643 pour la « Direction et Intendance générale » du projet de monts-de-piété à Paris et, au travers du royaume, il jouit de la protection du duc d'Orléans et du prince de Condé. Son projet rivalise directement avec l'entreprise du «bureau d'adresse » de Théophraste Renaudot et il est probable que Gerbier ait été manipulé par d'autres dans le cadre d'une campagne pour révoquer le brevet de Renaudot ${ }^{4}$.

4 Néanmoins l'entreprise propre de Gerbier devient l'objet de critiques de la part de la Sorbonne devant le Parlement de Paris dès 1648. Le soutien de la reine mère, Anne d'Autriche, dont il bénéficie, attise les flammes de la critique populaire des principaux dévots. Le projet de Gerbier devient une des premières victimes de la Fronde et son brevet est révoqué à son tour.

5 Dès la fin de l'été 1648, Gerbier est donc prêt à regagner l'Angleterre. Un de ses fils se joint à la cause royaliste sans son assentiment et contre son gré5. Ces trois filles sont brièvement internées dans un couvent à Paris et Gerbier est accusé de les avoir obligées à célébrer la foi réformée contre leur gréb. Avec la fin de la seconde guerre civile en Angleterre et l'aggravation de la situation politique à Paris à la veille de la Fronde, il espère rentrer pour établir une " Académie dans le style Français » pour l'éducation des gentlemen ${ }^{7}$. Son expérience des efforts faits à la cour de Charles $\mathrm{I}^{\mathrm{er}}$ pour inspirer de nobles vertus à travers l'éducation, liée à son admiration pour l'académie du Prince Maurice de Nassau établi en 1619 aux Pays-Bas, le convainquent que, si de telles académies sont à la mode en France, elles peuvent aussi le devenir au-delà de la Manche ${ }^{8}$. Il voit sa "Minerve d'Albion" comme un moyen de mettre à profit ses capacités en français, sa connaissance des fortifications, des mathématiques, de la géographie et de la cosmographie. Durant l'été 1648, il rédige un prospectus pour l'Académie, intitulé «The Interpreter of the Academie for Forrain Languages and all noble sciences and exercises » et part à la recherche de moyens pour recueillir un soutien pour ce nouveau projet ${ }^{9}$.

6 C'est par un ami commun, un docteur hollandais (résidant alors faubourg SaintGermain à Paris), le $\mathrm{D}^{\mathrm{r}}$ Arnold Boate, que Gerbier fait la connaissance de Samuel Hartlib. Comme Gerbier, Hartlib a fait partie de la communauté étrangère de Londres. Il est né à Elbing et n'est résident permanent de Londres que depuis la fin des années $1620^{10}$. Gerbier lui a peut-être paru comme une âme sœur. Hartlib avait lui aussi tenté d'établir une académie pour les gens de bonne famille et ses efforts convergents vers une réforme néo-baconienne par la diffusion des sciences dans la société se développent à la suite de la seconde guerre civile. Hartlib avait publiquement proclamé son intention d'établir un "Office of Address and correspondency " (selon les lignes établies par Renaudot) en 1647 et de nouveaux l'année suivante ${ }^{11}$. Gerbier voulait avant tout utiliser son expérience d'entrepreneur. Il voulait qu'Hartlib publie à la ronde des exemplaires de son prospectus dans tout le royaume grâce à son important carnet d'adresses ${ }^{12}$. En même temps, il espérait que celui-ci en envoie "to forraine parts", notamment à Dantzig, en Silésie, à Hambourg, en Hollande et ailleurs où ses contacts à l'étranger 
étaient particulièrement nombreux ${ }^{13}$. Il attendait de lui qu'il s'occupe d'une réédition du pamphlet à Londres, étant donné les défauts manifestes de la première édition, et donna des instructions pour faire inclure sa gravure dans la réédition ${ }^{14}$. Il alla même jusqu'à oser demander à ce charitable Hartlib de l'assister dans ses démêlés avec ses créanciers qui pillèrent sa maison de Bethnal Green quand son beau-père mourut en décembre 1648.

7 Mais le fait de donner et de recevoir de l'information faisait partie de la culture d'échange de cadeaux du dix-septième siècle. Le croquis et la brève description de la machine de Pascal était comme un gage d'amitié destiné à Hartlib, dans l'espoir de faveurs en retour. Gerbier n'avait eu aucune difficulté à voir la machine. Pascal avait fait en sorte que l'on puisse la voir chaque jour de la semaine et les samedis après-midi dans la maison de Roberval, professeur ordinaire de mathématique au Collège de France ${ }^{15}$. La curiosité de Gerbier pour la machine avait sûrement été initialement éveillée comme celle de Roberval lui-même, au salon de l'hôtel de Condé où avait été montrée et présentée la machine ${ }^{16}$. La décision de Pascal d'exposer la machine de façon permanente à la vue du public avait été judicieuse. Il l'avait conçue, comme il l'a expliqué, à des fins pratiques. Il espérait particulièrement attirer l'attention du receveur des finances, et quiconque travaillait pour les finances du roi, afin que sa machine soit utilisée pour faire leurs comptes. Il comprenait aussi les réactions d'hostilité que sa nouveauté pouvait produire ; les receveurs français utilisaient encore des jeux de jetons de couleur pour faire leurs calculs, ce qui demandait (d'après Pascal) " une longue suite et extension de jetons ${ }^{17}$ ". La Chambre des Comptes les obligeait à présenter leurs comptes en chiffres romains, plutôt qu'en chiffres arabes. Des peines sévères étaient encourues si une erreur se glissait dans les comptes. La tradition et le conformisme pesaient lourd dans le fonctionnement de cette administration. Si, à une date ultérieure, un brevet ou un monopole pour la conception et la production d'une telle machine aurait eu quelque valeur, la réticence des conservateurs face au progrès devait être vaincue par une démonstration publique des vertus de la machine. En tout cas, comme Pascal l'a dit lui-même (et comme le diagramme de Gerbier le montre), l'innovation était plus facilement montrée que décrite ${ }^{18}$. D'après la description et le diagramme, il est clair que Gerbier n'a vu qu'une version de la machine calculant jusqu'à 5 chiffres et sans programme différenciant « sous » et « deniers », qui fut ajouté à des versions ultérieures.

Quelle opinion Gerbier a-t-il eue de ce qu'il a vu? Les réactions de l'Europe entière étaient généralement enthousiastes et favorables à cette innovation. Mais Gerbier était plus difficile à satisfaire. L'instrument n'était pas en mesure, sauf après un grand nombre de calculs et une large marge d'erreur, d'effectuer des multiplications ou divisions compliquées. La machine se révélait à ses yeux peu transportable et trop chère. Il se rappelait un instrument dont il avait entendu parler « il y a quelques 24 ans passés » en Angleterre et qui effectuait plus ou moins les mêmes calculs. C'est sans doute une référence aux baguettes ou « os » de John Napier, décrits dans l'appendice de son Rhabdologiaie, publié à Édimbourg en 1617. Plusieurs séries des «os » de Napier, parfois organisés sous forme de panoplie, ont survécu depuis le dix-septième siècle et indiquent que la conception de Napier a été réalisée sous plusieurs formes ${ }^{19}$. Pour conclure, Gerbier pensait qu'il était nécessaire d'avoir un bon sens de l'arithmétique avant de pouvoir s'en servir. En ce qui concerne cette dernière affirmation, on ne peut pas dire que Gerbier n'y ait pas réfléchi auparavant. Son « interprétation» est basée sur l'apprentissage des principes mathématiques en cours dans son Académie. Il revient à 
la machine de Pascal dans son prospectus pour l'Académie, la classant comme impropre à l'exercice ou l'apprentissage de l'arithmétique :

Je veux...admonester les Amateurs des Sciences de Chercher le plus Solide, plus Seur, et le plus prompts ; de rejetter toutes les machines qui détournent les Esprits, et ne tirent la pratique assurée sinon en longueur, et en frais: Comme est la nouvelle Roüe du Sr Pascall à Paris, laquelle quoy que tres rare en ses opperations d'Arithmetique couste trop et n'est pas si practicable comme la plume, le Creon, ou le poinçon a depescher matiere ${ }^{20}$.

9 L'académie de Gerbier fut finalement inaugurée dans sa maison de Bethnal Green en septembre 1649. Hartlib aurait été l'invité d'honneur de la conférence inaugurale ${ }^{21}$. Elle ferma cependant au bout de deux ans et Gerbier dut fuir à nouveau et chercher fortune à l'étranger, cette fois aux Pays-Bas. Il n'est pas impossible qu'Hartlib ait fait circuler la lettre de Gerbier plus largement. Samuel Morland connaissait Hartlib depuis 1655 et partageait son intérêt pour les curiosités mécaniques ${ }^{22}$. Or Morland devait créer en 1661 une machines à calculer semblable à celle de Pascal, plus compacte encore ${ }^{23}$. On a souvent dit qu'il s'est inspiré d'un exemplaire de la Pascaline observée à la Cour de la Reine Christine de Suède ou durant une visite à Paris en $1655^{24}$. Il est néanmoins possible que son intérêt pour la machine de Pascal ait été éveillé à cette occasion, et qu'il chercha, par le biais de Samuel Hartlib, à communiquer ses dessins. Il était peutêtre inévitable que Morland, comme Pascal, se soit trouvé confronté à la difficulté des fabricants de réaliser leurs machines, par manque de capacité technique en la matière. ${ }^{25}$. Mais Morland bénéficiait peut-être d'un avantage dans ce domaine. Hartlib avait plus de facilité à entrer en contact direct avec les artisans londoniens, qui étaient dotés de bien meilleures compétences que ceux que connaissaient Pascal et ses associés. Le cercle de relations d'Hartlib était donc d'autant plus propice à l'exploration et à l'exploitation d'idées nouvelles venant de l'étranger.

\section{Texte de la lettre de B. Gerbier éditée par M. Greengrass}

\section{Transcription de la lettre de Sir Balthasar Gerbier adressée à Samuel Hartlib le 4 octobre}

1648. La ponctuation a été légèrement modernisée et les repentirs occasionnels de l'auteur ne sont pas indiqués.

[10/2/12A] Paris 4 me October 1648

Sir/

I haue both your of the 11th and 14th past (your Stil) att one time; and my printed paper with one of yours : My Apologie on the first ${ }^{26}$ js partly what I said before, that I doe not jntend to sett upp an ABC. Schoole for the English tongue ${ }^{27}$ : to which I must add that my friends haue been so neglectfull jn putting other things to the presse att London as that I haue been constrayned to unskillfull presses att Dieppe, where I had no man to ouerssee the essayes, thus I lett the things go: I do pray you to try how jt can be mended. For jt is absolutly necessary to advertise Fathers of families who haue Sons (lurking jn Chimney corners) to dispose to Learning And what should they remayne for Idle all the winter And as jt is an undertaking of charge this course must be taken before hand, cause then (I pray) the papers to bee printed ouer again and I will pay for the Charges,

I do according to your desire send you the first Lineament of my jntended Vocabularie, whick I do make jn all those languages mentioned jn my printed Paper to which the English must bee put. Butt that I will referre to a good English man jn Language and Ortographie : one of my Sons abroade may serue turne for that I haue 
begunne by the French, bycause jt is the Language for the which the English do commonly start outt of England, they shall then jff they please beginne with the same, and so proceede on to the other Languages : You will finde that my Invention is to facillitate to Lovers of Sciences the wayes to optaine them, Since by learning this Vocabularie they may get the Theoricall part by learning the Language. On every Science mentionned jn my printed papers I do make such a discoursse as you see I have begunn [10/2/12B] I will according the subiect mixt the discoursses with various passages that shall bee of singular use to the reader and to Noble men's children.

I haue seene your Printed Paper and communicated the same to $\mathrm{M}^{\mathrm{r}}$ Doctor Boate $\mathrm{e}^{28}$ your friend and mine, your care is laudable, may jt meete with dispositions according the meritte of the same: why did not you send me what the weekly Intelligencer had printed of my design/ The copies of letters of 1640 concerning Monsieur Le Maire tells me no Neews, for I haue seene the Man long since, and I was with the honorable Countesse of Claire ${ }^{29}$ to see his Musicall Instrument. Which is Harmonious, he hath many things jn his head, butt is not befreended by the best Professors of Sciences and knowledge jn these parts, which want none that are excellent; he is a Narcissus off him selfe, and headdy on his one Inuentions; he hath jnuented neew names to the Notes of Musick, as iff you should say Ra. Jnsteed of Ré, which passeth for Idle among the Musiciens ; his Nepheu (a Iong stripling fine curlde heare, neate jn his band strings, and boote tops, and so forth) - makes much a do with a neew way of Cifering : Butt to tell you the trust I found that while I was loocking on his way I had cast upp the account eare he was gone half way to his one Inuention.

Heare is to be seene a rare worke Inuented by $\mathrm{M}^{\mathrm{r}}$ Pascall Sonne to a President Off this Parlement: It is a casse with Sundry wheeles att least thirty, it serue for Arithmetike : and here you shall haue a drauft of jt [10/2/13A] jn lue of which I should bee glad to see a drauft of a little deuise which was jnuented jn England somme 24 yeares past being a little board with copper things to turne with a stick to cast accounts ${ }^{30}$. This js the Instrument here att Paris. The Bocks is of Ebonne. Two foot In lenght ; 9 Inches broad; accordingly jn height : The wheeles are of Copper : and seeme as so many Dialls or watches, sett with numbers 1.2.3. 4. 5. 6. 7. 8. 9. 10., the two rowes aboue are copper round things, wheron appeare little white papers sett with Cifers; when the hand sturres with a Stick the wheeles belowe, those little round things aboue turne according the wheele beloowe moues, by $100 / \mathrm{m} / 1$., lesse, or more / the Calculation desired js made suddainly: The Bocks within contaynes the thirty weeles which moue according the hand turnes the uppermost wheeles, Butt a man must first be exact jn Arithmeticke before he can make use of this Instrument, which cost 50 pistols and no rulle of three can be made butt by two of these Instruments, which are not portatiue, and Infine a Rare Invention farre saught, and deare baught : putt them jn Storre house was the old Prince of Orange wont to saye and lett us proceede on the ordinary readdy way.

Now for what you haue payed for portage I am sorry my friend heare was so jll adrest to haue mercenary mony [10/2/13B] charged with the paquets : for what $\mathrm{M}^{\mathrm{r}}$ Beare hath told you concerning Creditors though jt should not fright nor retarde I should haue been glad friends had been more prouident jn doing things In time as I had desired them to do. Which was to agree with Creditors to settle the debt ${ }^{31}$ to bee payed jn three yeares by yearly proportions: I do not knowe what they are and whether I must pay them fot I thinke those of my familly are the mayne cause of the Debts. / they are not so much, and cannot reach to 250 II jn The king owith me neere two thousand pound disburst Monnies during my Residency att Bruxells; time will growe better by the grace of God. When men can be satisfied they must bee contented: the Creditors haue nothing to shewe. I will giue them my bond to pay them to the last farthing with use of the mony for theire forbearance, can they demande better condition? I am fully persuaded that they would accept them iff they were called to a man that can speake, Iff you would call upon $\mathrm{M}^{\mathrm{r}} \mathrm{Kipp}^{32}$ (who 
for his age cannot sturre from Bednall greene) and desire him to giue you a Note of the Creditors names, call them to you, and represent to them that they cannot be payed during my stay abroade ; butt may haue all theire due by a just composition of time; for I not demande a farthing of abatment ; butt to satisfy them to theire full content : You will oblige me very much by so doing, jt were butt to make a list of the names of the Creditors, therein sett the seuerall depts. [10/2/14A] And agreeing with them and cause them to signe the paper: I haue diuers just pretentions of monnies due to me which must be payed jn time, and therefore the Creditors cannot loose, iff they will be reasonnable, and theire owne friend And consider that when a man js out off all he cannot do any thing: I had jntreated you to looke about for a goodly habitation for our Academie ${ }^{33}$ This I pray you to do, without putting your selfe to troubles. I will be on your Skirts (honnest $\mathrm{M}^{\mathrm{r}} \mathrm{Hartlib}$ ) as soone I shall haue my Passe, and gotten monnies due to me from this Crowne, and which I haue disburst long since / Therefore lett us thinke on all what may further our gallant dessigne, which I will by the Grace of God putt jn the brauist Coursse as shall redounde to the glory of the Nation the generall good of fathers of families, and all Louers of Virtues and Knowlegde; besides diuers other good things, which will require dilligent applications; what a contentment is it for the Soule of man to do good! for as Seneca saith well, the remembrance of jt sticks to the Soule with Ioy; when to the contrary remorce and dispaire are the wages of jll doings, and that neuer departs, butt followith the soule as shadowes do unto Bodies : I wrotte unto you by my last that my friend $\mathrm{M}^{\mathrm{r}}$ Stanley att Linolne House had charged himselfe with my letter to the Speaker ${ }^{34}$ so that I haue no more to say on this businesse for you do cleerly see that I meane really to go for [10/2/14B] England. Prepare and smoode you all things fitt for the same and wee shall do good things : Can you not gett annother weekly Intelligencer to mention jn his pamflett my Intention right, and giue notice of a Vocabularie. Which shall teach a ready way to Sciences, lett my name appeare, for I will bee knowne jn the businesse since no man can blush jn doing well : Pray tell to $\mathrm{M}^{\mathrm{r}}$ Kipp that I haue receaued his letter concerning a Colonell prisonner here. That I will send his Mothers letter to him au Pont de Larche neere Rouen, and should bee glad to do him good for his Releasement. Butt those things concerne the State and they are things of [Complimery ?]

The Duke of Lorraine keepes a friend of myne att the castle of Antwerpe and will haue $\mathrm{m} / 3$ pistols for his Ransome which angers these so much as that faire words will not moue them to release the prisonners which they haue butt on certaine feeling considerations, besides that $\mathrm{jt}$ is no prudence for me to medle jn such a bisiness the times are troublesome and suspitious, the old saying must not be forgotten putt your finger jn the ground and smell jn what contry you are. The good old man thinkes that a word speaking can do the thing Butt the reuerse of the Medall js that a word speaking may do me a world off jll ; So Charity must beginner att home Etc / I should bee glad to know whether The Countesse of Claire hath receiued my letter. Its all I haue to say for the present and therefore With my hearty salutations I rest

Your humble seruant

$B$ gerbier

$\mathrm{M}^{\mathrm{r}}$ doctor Boate is very busy for his good wyffe js jn Labour.

\section{Traduction de M. Greengrass et D. Descotes}

Paris, le 4 octobre 1648

Monsieur,

J'ai reçu vos deux lettres du 11 et du 14 écoulés (dans votre style) en même temps, et mon imprimé avec l'une de vos lettres. Ma réaction à la première lettre est en partie liée à ce que je vous ai dit auparavant, que je n'ai pas l'intention d'établir une école alphabétique pour la langue anglaise ; à quoi je dois ajouter que mes amis ont 
été si négligents en mettant d'autres choses sous presse à Londres que j'ai été contraint de me soumettre ${ }^{[a]}$ à des presses sans habileté à Dieppe, où je n'avais personne pour surveiller les épreuves ; ainsi ai-je laissé aller l'affaire. Je vous prie vivement de trouver moyen de faire la correction. Car il est absolument nécessaire d'avertir les pères de famille qui ont des enfants (tapis au coin du feu) qu'ils voudraient disposer aux études (et pourquoi devraient-ils rester inactifs tout l'hiver?), et comme c'est une entreprise qui coûtera cher ce cours doit être pris ${ }^{[b]}$ d'avance. Arrangez-vous donc (je vous prie) pour faire réimprimer les papiers, et je paierai les frais.

Selon votre désir, je vous envoie le premier trait du Vocabulaire que je projette, que j'établis dans toutes les langues mentionnées dans mon imprimé. L'anglais doit y figurer. Mais pour cela je me rapporterai à un homme compétent en langue et en orthographe anglaises: l'un de mes fils qui se trouve à l'étranger pourrait s'en charger. J'ai commencé par le français parce que les Anglais commencent normalement à apprendre lorsqu'ils quittent l'Angleterre, ils pourront alors si tel est leur loisir commencer par l'apprendre, et de là passer aux autres langues. Vous verrez que mon invention sert à faciliter aux amateurs des sciences les moyens de les acquérir, parce qu'en apprenant ce vocabulaire ils pourront acquérir la partie théorique en apprenant la langue. Sur chaque science mentionnée dans mon imprimé je fais un discours semblable à celui que vous voyez que j'ai commencé. Selon le sujet je mêlerai les discours avec des morceaux variés qui seront d'un usage singulier au lecteur et aux enfants des gentilshommes.

J'ai vu votre texte imprimé et l'ai communiqué au Docteur Boate, votre ami et le mien. Votre souci est louable, puisse-t-il rencontrer un accueil en accord avec son mérite. Pourquoi ne m'avez-vous pas envoyé ce que l'Intelligencer hebdomadaire a imprimé sur mon projet? Les copies des lettres de 1640 concernant Monsieur Le Maire ne m'apprennent rien de neuf, car j'ai vu l'homme depuis longtemps, et j'étais avec l'honorable Comtesse de Clare pour voir son instrument de musique, qui est harmonieux ; il a beaucoup de choses dans la tête, mais il n'est pas soutenu par les meilleurs professeurs de sciences et de savoir dans ces domaines qui ne veulent personne d'excellent ${ }^{[c\}}$. C'est un Narcisse de lui-même, et entêté de ses propres inventions. Il a inventé de nouveaux noms pour les notes de musique, comme si l'on disait Ra au lieu de Ré, ce qui est considéré comme futile parmi les musiciens. Son neveu, jeune adolescent aux cheveux bien frisés, tout joli avec ses galons et ses souliers à talons hauts, et le reste à l'avenant, fait beaucoup de bruit avec sa nouvelle méthode de calcul. Mais à vous dire la vérité, je me suis aperçu que pendant que j'assistais à sa manière de procéder, j'avais fait le compte avant qu'il soit arrivé à mi-chemin de son invention.

On peut voir ici un rare ouvrage inventé par M. Pascal, fils d'un Président de ce Parlement. C'est une boîte avec diverses roues, trente au moins; elle sert pour l'arithmétique. Vous trouverez ci-dessous un dessin, en échange duquel je serais heureux de voir un dessin d'un petit instrument qui a été inventé en Angleterre il y a quelque 24 ans, savoir un petit tableau avec des objets de cuivre à tourner avec un bâton pour faire les comptes. Voici l'instrument qui se trouve ici à Paris. La boîte est en ébène, de deux pieds de longueur, 9 pouces de largeur et de même hauteur. Les roues sont en cuivre, et ressemblent à autant de cadrans ou de montres, pourvus de nombres $1,2,3,4,5,6,7,8,9,10$, les deux rangs supérieurs sont des objets de cuir ronds, sur lesquels apparaissent de petits papiers blancs portant des chiffres ; lorsque la main fait mouvoir avec un bâton les roues d'en bas, ces petites choses rondes au-dessus tournent selon le mouvement de la roue inférieure dans la proportion de 100,000 à 1 de plus ou de moins; le calcul désiré est effectué immédiatement: l'intérieur de la boîte contient les trente roues qui se meuvent selon que la main tourne les roues du dessus.

Mais on doit d'abord être au point en arithmétique avant de pouvoir se servir de cet instrument, qui coûte 50 pistoles, et il faut deux de ces machines pour effectuer une règle de trois; elles ne sont pas portatives, et enfin c'est une invention rare, 
cherchée loin, et achetée cher : mettez-les en magasin, avait l'habitude de dire le vieux Prince d'Orange, et procédons par la plus facile et ordinaire manière.

Maintenant, concernant ce que vous avez payé pour le port, je suis désolé que mon ami d'ici ait été assez maladroit pour avoir fait payer le port des paquets en argent comptant. Pour ce que M. Beare vous a dit sur les créanciers, quoique cela ne devrait ni inquiéter ni retarder, j'aurais été heureux que des amis se soient montrés plus prudents pour mener les affaires dans les délais que j'avais souhaités, c'est-àdire pour s'accorder avec les créanciers pour convenir que les dettes seraient payées en trois ans par versements annuels. Je ne sais pas ce qu'elles ${ }^{[\mathrm{d}]}$ sont et si je dois les payer, parce que je pense que des membres de ma famille sont la principale cause des dettes. Elles ne sont pas si importantes et ne peuvent atteindre 250 livres $^{[\mathrm{e}]}$ en tout. Le Roi me doit près de deux mille livres d'argent déboursé pendant ma résidence à Bruxelles ; l'avenir s'améliorera par la grâce de Dieu. Lorsqu'on peut être satisfait, on doit être content: les créanciers n'ont rien à réclamer. Je leur donnerai ma garantie de les payer jusqu'au dernier sou avec les intérêts de leur argent pour leur patience, peuvent-ils demander meilleure condition? Je suis pleinement persuadé qu'ils accepteraient s'ils pouvaient s'entretenir avec quelqu'un qui sait parler; si vous rendiez visite à M. Kipp (qui à cause de son âge ne peut bouger de Bethnal Green) et lui demandiez de vous donner une liste des noms des créanciers, vous pourriez les convoquer et leur représenter qu'ils ne peuvent être payés durant mon séjour à l'étranger ; mais qu'ils peuvent avoir tout leur dû moyennant un juste accommodement sur les délais; car je ne demande pas un sou de remise; mais je ne veux que les satisfaire pleinement. Vous m'obligerez beaucoup en faisant cela, ne fût-ce que de faire la liste des noms des créanciers, et d'y mettre les dettes respectives, et en s'accordant avec eux, les amener à signer le papier. J'ai plusieurs justes titres pour recevoir de l'argent qui m'est dû et qui doit m'être payé à temps, et par conséquent les créanciers ne peuvent pas y perdre, s'ils se montrent raisonnables et s'ils ont le sens de leur propre intérêt, et s'ils considèrent qu'un homme complètement dépourvu de moyens ne peut rien faire. Je vous avais demandé de chercher un beau logement pour notre Académie, je vous prie de le faire, sans vous donner de tracas. Je serai, honnête M. Hartlib, pendu à vos basques aussitôt que j'aurai obtenu mon passeport et l'argent qui m'est dû par la Couronne et que j'ai dépensé depuis longtemps. Pensons par conséquent à tout ce qui pourra avancer notre généreux projet, que par la grâce de Dieu je mettrai sur le meilleur cours, tel qu'il rejaillira à la gloire de la Nation, le bien général des pères de famille, et de tous les amoureux des vertus et du savoir; sans compter divers autres biens, qui demanderont des soins diligents ; quel contentement est-ce pour l'âme humaine de bien faire! car comme disait bien Sénèque, le souvenir du bien enfonce la joie en l'âme ; alors qu'au contraire le remords et le désespoir sont le salaire du mal faire, et ne s'en vont jamais, mais suivent l'âme comme les ombres suivent les corps : Je vous ai écrit dans ma dernière lettre que mon ami M. Stanley de Linolne ${ }^{[f]}$ House s'est chargé de ma lettre au Speaker, de sorte que je n'ai plus rien à dire sur cette affaire car vous voyez clairement que j'ai réellement l'intention de partir pour l'Angleterre. Préparez et disposez toutes choses qui peuvent conduire à cette fin, et nous ferons du bon travail. Ne pourriez-vous obtenir qu'un autre Intelligencer hebdomadaire mentionne dans sa brochure mon intention correctement, et annonce un Vocabulaire qui enseignera un accès facile aux Sciences; que mon nom y apparaisse, car je veux être connu dans l'affaire car personne ne peut rougir de bien faire : S'il vous plaît dites à $M$. Kipp que j'ai reçu sa lettre concernant un colonel prisonnier ici. Que je vais lui envoyer la lettre de sa mère au Pont de l'Arche près de Rouen, et que je serais heureux de le servir pour sa libération. Mais ces choses concernent l'État et ne sont pas des choses de (mot illisible).

Le duc de Lorraine garde un de mes amis au château d'Anvers et réclame 3000 pistoles pour sa rançon, ce qui irrite les gens d'ici à tel point que de belles paroles ne les amènent pas à relâcher les prisonniers qu'ils ont (sauf sous certaines 
considérations de sympathie); d'ailleurs il n'y a pas de prudence pour moi à me mêler d'un pareille affaire, les temps sont troublés et pleins de soupçons, il ne faut pas oublier le vieux dicton, mettez votre doigt dans le sol et sentez dans quel pays vous êtes. Le bon vieil homme pense qu'un mot dit de vive voix peut faire l'affaire. Mais le revers de la médaille est qu'un mot dit de vive voix peut me causer un monde de tort. De sorte que la charité doit commencer par soi-même, etc. Je serais heureux de savoir si la comtesse de Clare a reçu ma lettre. C'est tout ce que j'ai à dire pour le moment et par conséquent avec mes salutations du fond du cœur, je demeure

votre humble serviteur

B. Gerbier

M. le docteur Boate est très occupé car sa bonne épouse est en train d'accoucher.

[a] C'est-à-dire : soumettre mes écrits...

[b] C'est-à-dire : payé ou réservé.

[c] C'est-à-dire : ces professeurs ne veulent pas soutenir M. Le Maire, de peur qu'il ne les dépasse.

[d] Les dettes.

[f] Livres sterling.

[e] Lire : Lincolne? 


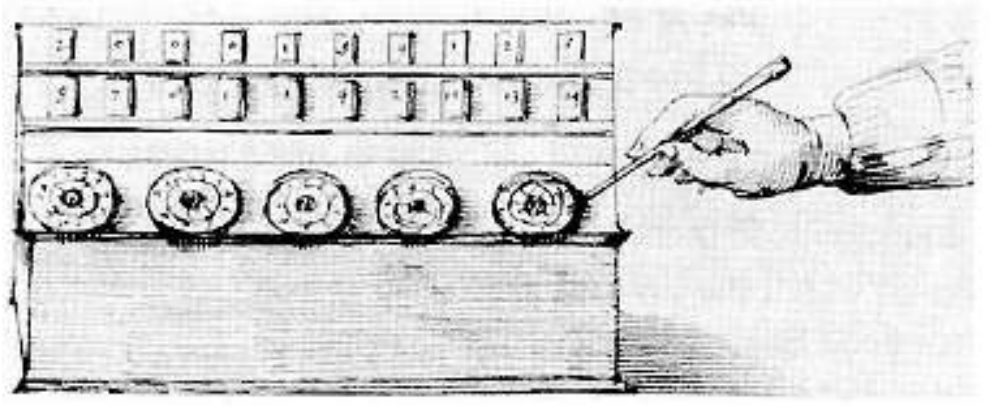

Le texte de la lettre de B. Gerbier suppose qu'il a vu une machine sans doute destinée au calcul abstrait.

Cependant la comparaison de son dessin avec les exemplaires connus de la Pascaline appelle quelques remarques.

La figure ne représente pas les armes de Pascal sur la face antérieure du boîtier. C'est aussi le cas de certains exemplaires conservés aujourd'hui.

Le dessin ne semble pas comporter la réglette mobile qui dissimule une rangée de fenêtres en dévoilant l'autre, selon qu'on veut additionner ou soustraire. II montre donc, bien visibles, les deux rangées de chiffres inscrits sur les tambours.

Le nombre des couples de fenêtres dessiné est de 10, soit deux fois plus que de roues, alors que sur la Pascaline, le nombre des roues et celui des couples de fenêtres est nécessairement égal. La roue de gauche est située trop au bord du boîtier. On notera aussi que le dessin reproduit les roues sans le butoir nécessaire pour arrêter le mouvement du stylet.

Les nombres qui apparaissent aux fenêtres ne sont pas conformes à l'original, car ils ne sont pas complémentaires, comme c'est le cas sur les Pascalines. Les trois fenêtres de droite de la rangée inférieure présentent les nombres 11, 13 et 14, qui ne peuvent apparaître sur une machine destinée au calcul abstrait, pas plus que le 10 mentionné dans le texte de la lettre : ces nombres ne sont possibles que sur les machines destinées aux comptes financiers. Noter que Gerbier oublie le 0, qui figure toujours sur les tambours.

Voir Guy MOURLEVAT, Les Machines arithmétiques de Blaise Pascal, La Française d'Édition et d'Imprimerie, Clermont-Ferrand, 1988.

D. Descotes

\section{NOTES}

1. Collection Hartlib de l'Université de Sheffield (CH ci-dessous).

2. 10/2/12a-15a. Voir appendice.

3. La seule étude désigne de ce nom (et non des moindres) qui ait été faite sur Gerbier est incluse dans Four Stuart Portraits (Londres, 1649) de H. Ross Williamson. Une biographie sommaire et contenue dans le Dictionary of National Biography sous «Gerbier». La plupart des points biographiques de ces articles proviennent de son propre fragment autobiographique:A Manifestion By Sr B. G., Kt (Londres, 1651).

4. Howard M. Solomon, Public welfare, science, and propaganda in seventeenth-century France (Princeton University Press, Princeton, 1992), p. 193.

5. Dans une lettre du 24 mars 1649 adressé à Hartlib (10/2/28a-b), Gerbier se plaints qu'un des fils a été « débauché contre l'avis de ses parents » à «prendre les armes » à Oxford par un certain William Sanderson.

6. Voir sa publication: A letter from sr B. G. Kt, to his three daughters inclosed, in a nunnery at Paris (n. 1. [Rouen?], 1646). 
7. Voir $\mathrm{CH}$ 10/2/ la (27 août 1648).

8. Pour le modèle et les objectifs pédagogiques de ces académies, voir F. Yates, The French Academies in the sixteenth century (Londres, Warburg Institute, 1947) ch. 12; et E. Schalk, From Valor to Pedigree. Ideas of nobility in France in the sixteenth and seventeenth centuries (Princeton University Press, Princeton, 1986), ch. 8.

9. The Interpreter of the Academie for Forrain Languages and all noble sciences and exercises... The first part (London, 1648). Une version incomplète ou inachevée de ce texte en français se trouve dans $\mathrm{CH}$ 10/2/47a-60b ( Petit Truchement pour ceux qui sont désireux d'apprendre les langues, les sciences et les exercices Nobles et Nécessaires. En la Minaervae d'Albion sous la surveillance de Chevallier Balthazar Gerbier... »).

10. Pour la vie de Samuel Hartlib, voir G. H. Turnbull, Hartlib, Dury and Comenius (Liverpool and London, Hodder and Stoughton, 1947), $1^{\text {re }}$ partie.

11. Ibid, p. 92.

12. «... to particular Noble families, as also to the principall Innes of the Townes of remarke »CH 10/2/1b (Gerbier à Hartlib, 27 août 1648).

13. $\mathrm{CH} \mathrm{10/2/21a-22} \mathrm{(Ibid.,} 28$ novembre 1648).

14. CH 10/2/20a (Ibid., 31 octobre 1648). Et aussi 10/2/25a-26b (Ibid., 26 décembre 1648).

15. L. Brunschvicg et P. Boutroux, œuvre de Blaise Pascal, (Paris, 1908) I, 294.

16. Ibid., I, 282.

17. Les receveurs dépendaient fréquemment de nouveaux jeux de jetons pour les assister pour dans leur comptes; voir e.g. AD Haute-Garonne C 693 (Comptes de Me Jean Tryat, 1572, pour le diocèse civile de Toulouse : 1 livre 5 sous pour «deux comptes de gectons pour en faire le calcul... »).

18. Bien qu'un simple croquis, le dessin de Gerbier indique clairement, comme d'autres exemples de son art l'attestent (Pepys collection, Magdalen College, Cambridge, que celui-ci était un expert dans l'art de dessiner la mémoire.

19. Voir E. M. Horsburgh (ed.) Handbook of the Exhibition of Napier relics and of Boocks, Instruments, \& devices for facilitating calculation (Edimbourg, Royal Society of Edinbourg, 1914), pp. 14-5 ; 17-9.

20. $10 / 2 / 58 b$.

21. 10/2/30a : Affiche d'une disputation publique à Bethnal Green, 1 septembre 1649, devant « his noble vectroies [victorious ?] frind $\mathrm{M}^{\mathrm{r}}$ Hartlib and family ». Voir aussi The First Lecture of an Introduction to Cosmographie (which is a descritpion of all the World), read publickly at Sr B. Gerbier his Academy at Bednall-Green (London, 1649).

22. H. W. Dickinson, Sir Samuel Morland. Diplomat and Inventor, 1625-1695) (Cambridge, The Newcomen Society, 1970). Pour le début de leur correspondance sur l'échange information sur les instruments mécaniques, voir le journal d'Hartlib ou Ephemerides pour 1655 (29/5/13a) : « The 19 of February Mr Morland came to mee the first time being recommended byv $\mathrm{M}^{\mathrm{r}}$ Haack... he is of a communicative nature long in Sweden, altogether Mathematical and Mechanical. Laboured much in the Perpetuus Motus. "

23. Le premier exemplaire de la machine de Morland est daté de 1666, mais la correspondance de Cosimo Brunetti, écrivant de Londres au Grand-duc de Toscane, fournit une description détaillée et un diagramme de la machine en 1661. Voir M. Miniati, «Le savoir scientifique et ses instruments en Italie au XVII ${ }^{\mathrm{e}}$ siècle » dans Diffusion du savoir et affrontement des Idées, 1660-1770 (Montbrison, 1993), p. 151.

24. Ibid., pp. 28-9.

25. Ibid., p. 31. Pour les problèmes de Pascal, voir EEuvre, 1, 300: «N'ayant pas l'industrie de manier le métal et le marteau comme la plume et le compas, \& les artisans ayant plus de connoissance de la pratique de leur art que des sciences sur lesquelles il est fondé, je me vis reduit à quitter toute mon entreprise... » 
26. La lettre d'introduction de Gerbier à Hartlib où il expose son projet d'Académie date du 27 août 1648 (HP 10/2/1a-b).

27. La proposition de Gerbier n'est pas d'installer une école élémentaire pour l'apprentissage des langues, mais un projet d'Académie moderne pour l'éducation de jeunes gentlemen, dans la lignée d'académies similaires en France, et peut-être pas si différente de celle qu'Hartlib lui-même avait projetée à Chichester au début des années 1630 . Il subsiste quatre versions du prospectus, datant de 1648, qui confirment les difficultés de Gerbier à le publier et à le distribuer comme il le voulait.

28. Pour la carrière d'Arnold Boate, voir C. Webster, The Great Instauration (London, Duckworth, 1975), pp. 64-5.

29. Elisabeth Holles, comtesse de Clare, avait déjà eu l'occasion de prouver son dévouement à Balthazar Gerbier. Elle s'était personnellement assurée de la bonne garde de ses filles et Gerbier lui demanda de véhiculer de la publicité pour son académie.

30. Certainement une référence au "promptuaria » de John Napier, décrit son Rhabdologiae seu numerationis per virgulas libri duo (Édimbourg, 1617). Napier avait élaboré une méthode de "numérisation par baguettes » qui, puisque celles-ci étaient souvent fabriquées en os ou en ivoire, fut connue sous le nom d'« os de Napier ». Quoique la description de Napier porte sur des baguettes carrées, celles-ci pouvaient aussi prendre la forme de cylindres fins, ce qui aurait pu engendrer une confusion avec les cadrans à résultats de la machine de Pascal. En réalité, elles fonctionnaient très différemment.

31. Parmi les dettes que Gerbier encourut pour le compte de Charles $\mathrm{I}^{\mathrm{er}}$ pendant sa période de service à Bruxelles, la plus élevée se montait à 1300 livres, le coût d'un diamant monté en bague qu'il acheta pour offrir (d'après les instructions du roi) au comte de Solms ; voir W. D. Hamilton (ed.), Calendar of State Papers Domestic 1641-3 (London 1887), pp. 293-4.

32. $\mathrm{M}^{\mathrm{r}}$ Kipp était le beau-père de Gerbier, probablement d'une famille marchande flamande.

33. Gerbier avait pensé à plusieurs endroits pour son académie - y compris la vallée de la Loire, Edimbourg, York et ailleurs, mais il se décida enfin pour Londres. Il espérait qu'Hartlib lui trouverait une propriété à Moorefields, juste en dehors de la Ville. En fait, l'Académie devait ouvrir ses portes dans sa maison de Bethnal Green.

34. Ceci était une lettre de recommandation adressée au Speaker afin d'acquérir le passeport nécessaire à son voyage de retour en Angleterre.

INDEX

Mots-clés : Pascal, machine à calculer, Gerbier (Sir Balthazar), Hartlib (Samuel), pascaline

Keywords : Pascal, calculating machine, Gerbier (Sir Balthazar), Hartlib (Samuel), pascaline

\section{AUTEUR}

MARK GREENGRASS

Université de Sheffield 